\section{New Application of Chemical Biology}

\section{Liqiang Zhang*}

Center of Bio Energetics, The Biodesign Institute, Arizona State University, USA

It is hard to search when people tried to develop chemical approaches for biological research, but the term of "chemical biology" has come into wide use for not more than two decades. As a complex hybridization of chemistry, biochemistry, biology and pharmacology, chemical biology has made numerous triumphs with booming biomedical science in the last decade [1].

Except the application of NMR and mass spectra (MS) to the research of biology, another well known accomplishment of chemical biology is synthetic small-interfering RNA (siRNA) duplexes. Now it is one of the most powerful tools for biological mechanism study by lossof-function assay. Besides successes in research tools, chemical biology has made very prominent progress in the field of diagnostics. No doubt, to develop lower-cost and easier approaches with higher sensitivity and specificity is only direction of chemical biology in future. Scientists have made very significant successes recently, such as nanoparticles for targeting and visualizing tumor tissues [2], DNA synbodies which is new affinity reagent that could offer an easy-to-produce alternative to traditional antibodies [3]. Researchers are also trying to develop new sensors to diagnose HIV at low cost [4].

Chemical biology has not only been applied to the development of probes, but also has made remarkable success in drug discovery. Since the development of imatinib (Gleevec), which is the first of new drugs acting as a specific inhibitor to a certain enzyme, was cited as a major success for chemical biology [5], couple of other specific inhibitors to certain enzyme (most are kinase) or receptor have been developed and tested, such as inhibitors of phosphoinositide 3- kinase (PI3-K) and inhibitors of epidermal growth factor receptor (EGFR). Some of them have been approved by US Food and Drug Administration (FDA).

Considering the disadvantages of nuclear medicine and limits of radiation therapy, chemical biologist may bring into full play the advantage of chemical biology in specific cellular targeting to improve those disadvantages and overcome limits in the short future.

\section{References}

1. Bucci M, Goodman C, Sheppard TL (2010) A decade of chemical biology. Nat Chem Biol 6: 847-854.

2. Fan K, Cao C, Pan Y, Lu D, Yang D, et al. (2012) Magnetoferritin nanoparticles for targeting and visualizing tumour tissues. Nat Nanotechnol 7: 459-64.

3. Liu R, Jiang B, Yu H, Chaput JC (2011) Generating DNA synbodies from previously discovered peptides. Chembiochem 12: 1813-1817.

4. www.grandchallenges.org

5. Druker BJ, Talpaz M, Resta DJ, Peng B, Buchdunger E, et al. (2001) Efficacy and safety of a specific inhibitor of the BCR-ABL tyrosine kinase in chronic myeloid leukemia. N Engl J Med 344: 1031-1037.
*Corresponding author: Liqiang Zhang, Center of Bio Energetics, The Biodesign Institute, Arizona State University, USA, E-mail: Liqiang.Zhang@asu.edu

Received July 01, 2012; Accepted July 05, 2012; Published July 07, 2012

Citation: Zhang L (2012) New Application of Chemical Biology. J Nucl Med Radiat Ther S7:e001. doi:10.4172/2155-9619.S7-e001

Copyright: $\odot 2012$ Zhang L. This is an open-access article distributed under the terms of the Creative Commons Attribution License, which permits unrestricted use, distribution, and reproduction in any medium, provided the original author and source are credited. 